
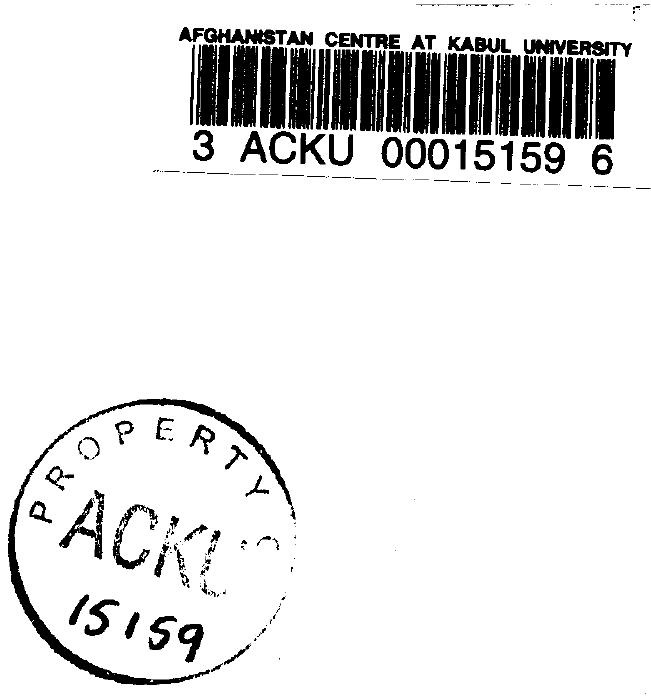

Afghanistan

KUNOUZ-KHANABAD Irrigation Feasibility Study

letter of transmittal dated Jan.1969 plan of operation signed Jan. 1969 
$-7 \rightarrow$ CONFORNED COPY

Page 1

IA:SF $68 / 97$

\section{UNITED NATIONS DEVELOPMENT PROGRAMME}

(SPECIAL FUND)

\section{plan of operation}

\section{Country: AFOHAMISTM}

I1t10 of Project, Kundu=-Khanabad Irrigation Foasibility Study 
Summary data

I. PURPOSE ATD DESCRIPTION

II. PRIOR OBLIGAMIONS

III. KORK PLAT

1. Partiolpation and Contribution of the Special fund . . . ' 10

B. Partioipetion and Contribution of the Government . - . . . 11

1. Counterpart Contribution . . . . . . . . . . . 11

11. Local Operating Costs - . . . . . . . . . . . 13

1ii. Privileger and Immuaties - . . . . . . . . . . . . 14

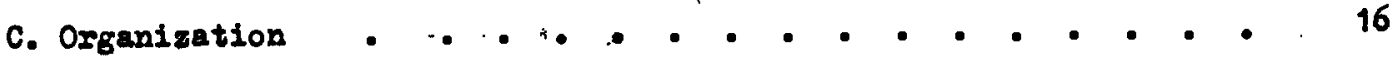

D. Sequence of Operatione . . . . . . . . . . - . . 20

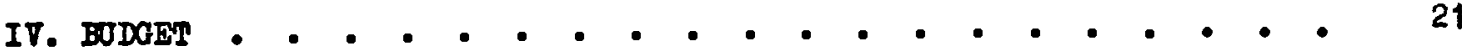

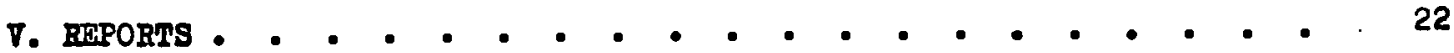

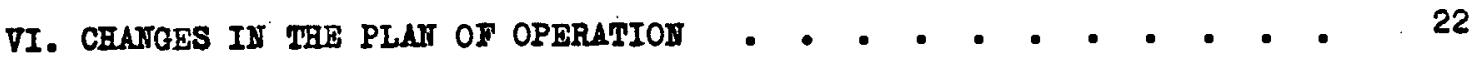

VII. STEPS TO BE TAKEAR AT THE CONPIETION OF SPECIAL HUND ASSISTATCE TO TEE

PBOJECT

SIGNATURE

\section{AP PENDICES}

I. Plan of Expenditure. Special Fund Aliocation . . . . . . . - 24

II. Plan of Expenditure. Gorernment Counterpart Contribution - • - 28

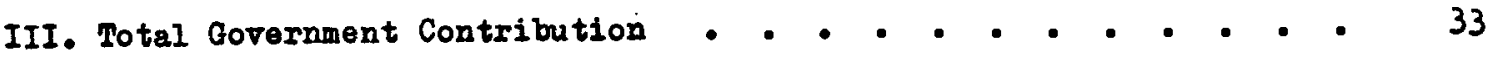

IV. Schedule of Operations - . • • • • • • • • • • • • • 34

Note

This Plan of Operation is in part based on frinted forms which are standard for all Special Fund-assiated projects. Whenever an item included in the forms is inapplicable an entry of "n.a." (not applioable) has been made. 


\section{UNITED NATIONS DEVELOPMENT PROGRAMME}

(SPECIAL FUND)

\section{PLAN OF OPERATION}

Country: AFGHANISTM

Titlo of Profects. Kundus-Khnnabad Irrigation Feasibility Study

sunery data

Special Fund allocation.

iss

$708,300 / 1 / S_{n}$

Consieting ofs

Spooial Mund contribution ....... US\$

Oorernment oontribution tovards

local operating costs . . . .. . US\$

doternment counterpart

contribition in cash ... . . USS

650,900

Hon nat

57,400

H.

SW Mat

Government oounterpart oontribution in kind

USt 290,440

\section{Daration Tro Years}

Participating and

Executing Agency

Co-operating Corernwent 4 genoy
Food and Agriculture Orcanization of the United Nations Lfghan Vater and Soll Survey Authority of the Yinistry of Lrioulture and Irrigation

P R E A M B L E

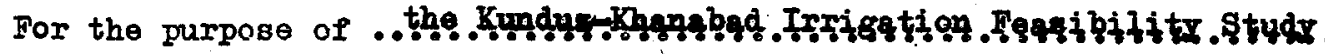
to be undertaken by the Food and Agrioulture

Organization of the United Nations, acting as the Participating and Frecuting Agency $1 /$ for the Special Fund, in co-operation with the Government of ..Afehantaten......... $\ldots \ldots \ldots \ldots \ldots \ldots \ldots \ldots \ldots \ldots \ldots \ldots \ldots . \ldots \ldots$ this Plan of Operation shall be the Plan of Operation provided for in Article I, paragraph 2, of the Agrement eigned on .... 21. Fabfugry. .1950. by the Covermment of. Archanintan and the Special Fund. It has been established in ..three.. original copies

$1 /$

For Heouting sgenoy in tho taxt read"Participating and freouting Agenog". 


\section{PURPOSE AND-DESCRIPTION}

\section{A. puapose of the praject}

(1.1) The purpose of the project is to carry out fonsibility gtudy for the development and expansion of irrigated agriculture in $a 20,000 \mathrm{hn}$ seleoted sone in the Kandusmanebad district, including the neossery institution and servieen, with a vier to defining the area's investment potontiel.

(1.2) In-particular the project wills.

(a) Cexry out aeriel survey and mepping of the area at roales of $1: 25,000$ and 1:10,000 principally for land clessifioation preposos.

(b) Caryy out goologionl and geophysicel investigstion to determine a ouitable irrigation dirergion dam site.

(o) Carry out a bydrologioal invegtigation of water arailability at this sito.

(d) Inrestigate the groundweter resources of the area.

(e) Propare and develop proposel for the improvenent of existing irrigation works and for the extension of the irrigation network.

(t) Framine all aspects of existing irrigation agrioul ture, inoluding auoh matters as oredit preotioes, resesroh servioes, extension practices, prioing prooedures and polioies and sooiologienl aepeote and

(c) Based on these tochnioal studies, a dorelopment plen for the projeot area $x i l l b e$ propared. Tho plen will inolude an estinate of tho oapital and soolel Investment required for the development of the area, as well in the direot and-indireot benefite expeoted fros suoh invertment. . 
Purpase and Dascription (eont inued)

\section{B. Descarptrar or tid phovet}

(1.3) The aren selected for the study comprises an area of 14,000 heotares which is already under irrigation, and an additional area of 6,000 heotares to whioh irrigetion will ultimately be extended. It lies on the left bank of the Khanabad river and is indicated as Zone VI on the attached map.

(1.4) Lerial ourveye and mapping will be oerried out by the Government an followese Prior to the commenoment of field operations

a) Larial photography of some 400 to $500 \mathrm{mq} \mathrm{km}$ over the project area $(350 \mathrm{mg}$ ) in the scale of $1: 25,000$ and $1: 10,000$ and delitery of. 5 sets of photographs

b) Control mosaios $(200 \mathrm{gq} \mathrm{km}$ ) in the sosle of 1810,000 and delitery of 5 setss

c) Meps at a soale 1:10,000 with $2 \mathrm{~m}$ contour (140 $\mathrm{kq} \mathrm{kan}$ ) and with $1 \mathrm{~m}$ contour (60 sq km) and delivery of 3 oxpnarg (transparent for osalid printing of the finithed drafted meps).

Draring the period of the project

d) Topographic survey at a sole 1:5,000 for cadestral purposen orer a pilot area of some 2,000 to 3,000 ha and at soale $1: 500$ and 1:200 for major structures of the projeot.

(1.5) Geophysionl Burreys using electrioal resistivity and/or seiamio methods will be made for the diveraion dam site, major canal lay-out, fround water resources, drainage, raterlogging and salinity investigations. Based on the geophyaical survey regults and their geologioal interpretation, drilling operations will be oarried out by the Covernment. 


\section{Pege 6}

(1.6) Hydrological investigations will be made to:

a) Lssess the availability of water from the Thanabad river, the extent of sediment load, magnitude and frequency of floods.

b) Appratie the effects of these factors.

c) Estimate water requiremente for existing - proposed cropping patterns. d) Assegs the groundwater resources in the project area.

For undertaking these hydrological investigations, the rehabilitation and operation of at least 3 hydrometric stations at Farkbar, Bangi and Pul-e-Chuga and a minimum of climatological stations will be required. (1.7) Iand olserification will be cerried out to a semi detailed standard on the basis of soil aurvey, aerial photographe and relevant prints and maps propared to soale of 1:10,000. Specifications for each land class and presentation of maps shall be in accordance with the U.S. Buresu of Reolamation's olasalfioations or of any other comparable intermational standerd. (1.8) An appraibal will be made of drainage problems, water logeing and salinity conditions, including if neoessery selt balance studien. (1.9) Bugineering designs will be propared suitable for oveluating quantitiea and relerant cost estimates for all project features of the selected area.

a) Diversion dam, canals, structures, laterals and drains,

b) Roads nocessery to operate and maintain the irrigation systen and to improve the existing main road to Kundus ria Khanabad,

0) Offices, workshope, warehouses etc.,

d) Iand levelling and on-farm derelopment works,

-) Flood protection of the project aree including murface run-off and from the Khanabad Hiver, and conservancy and training measures propesed. 


\section{Page 7}

(1.10) Studies will be made of crop water requirenents, conveyance losses, irrigation efficiency and the need for canal lining.

(1.11) Present agricultural practices in the project area rill be reviered and recomendations made on crops adaptable, cropping patterns, with projection over the life of the project, livestock production, prospects and proposals. Anticipated yields, value of crops and crop production costs, with and without the project; crop returns both eross and net, attributable to the projeot. (1.12) Land ornership, tenenoy, and size of holdings will be reviered. Becommendations will be made for any changea for project operations including consolidation, right - of way, expropriation etc. and cadartral survey. (1.13) Typical farm buagets will be prepered related to the existing and/or anticipated average holding and inoluding capital costs, operating costs, receipts and net farm income. Iret value of water will be shown. (1.14) The present and proposed facilities for Agricultural oredit will bo studied, taking into socount agrioultural credit policy and praotioes at oountry 1evel.

(1.15) Narkete will bo studied for present and future production, including internal and export markets.

(1.16) The need for cooperatives will be essessed with their possible role, and the roquirements for agricultural production prooesging industries and storage Pacilities.

(1.i7) Agricultural research fecilities and extension services will be studied and proposels made for requirements in relation to the project. (1.18) Govermment price policies on orops such as cotton, rioe, augar beet, wheat etc. should be determined and proposal made for any changes desirable in relation to the project. 
(1.19) The social aspects governing the Parmers willingess to participate in the project vill be otudied and assessed. (1.20) Health aspects of the proposed development will be studied and reoomendetions made.

(1.21) Problems of organization and management will be taken into aoount, in partioular:

a) Present and proposed organization for development of irrigation sohemes.

b) Managenent control, stafing, coordination with other Government agoncies, procurement, administration, infre-structure and operating costs.

- (1.22) Bonomic and financial aspocts will be studied, and benefits both direct and indireot resulting from project derelopment will be assessed. Internal rates of return will be shown for the existing area (14,000 ha) efter improveant, for the extension area $(6,000 \mathrm{ha})$ and for the whole development projeot $(20,000 \mathrm{ha})$ cost and benefit streams will be indiceted.

Finnoiel analysis and proposels for ropasment of projeot oosts including oredit on loens (foreign and lookl ourrenoy) to bo made for project construction (tares, water rates, eto.). 120 year life for the project vill be ooneidered for each flow projection computation. (1.23) The feasibility study report will be comprehensive enough to be mubaitted to financing inetitutions. The proposed development project to be presented as a result of the fessibility tudy will be, to the extent possible, a selfoontained one inoluding all othor agrioult ural inputs in addition to water and other faoilities, conotruction, operation and maintenanos supported by designo and cost estimates: it will be demonstration projeot as well leading to Introduction of modern agricultural preotices. (1.24) In all projeot operations, the in-sorvioe training of Lfghen personnol will form an importent element. 


\section{Page 9}

\section{PRIOR OBLIGATIONS}

Compliance with these obligatione at the appropriate time is a prerequisite to the implementation or the continuation, whichever is applicable, of project operatione.

(2.1)

$(2.2)$

$\pi / 1$

(2.3)

$(2.4)$ 


\section{WORI PLAN}

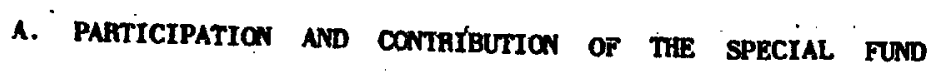

(3.1) The Special Fund shall provide the following through the Perticipating and Frecuting Agency:

a. Experts

A total of ... 33........ man-months of expert service. Within the total of ...33....... man-months of expert sorvice minor adjustments of individual post aspignments may be made by the Participating and Executing Afency, in consultation with the Covernment, if this is found to be in the best interest of the project.

b. Pellowships

Fellowships at an estimeted cost of $\$ \ldots .12,000 \ldots \ldots . . .$. Fellowahipe awerded under this Plan of Operation ebell be administered in acoordance with the fellowship. regulations of the Participating and Executing Agency. Within tho rotal allocation of \$...12,000....., minor adjustments of individual fellowships may be made if this

18 found to be in the best interest of the project.

C. Equipment and supplies

Equipment and supplies at a cost not exceeding $\$$........

d. Sub-contracts

sub-contraots at a cost not exoevding $\$$

Miscellaneous services and facilities, falling under local operating costa, at an estimated cost of $\$, 5,000$

(3.2) The Bervices and facilities oummarized in paragraph (3.1) above are detailed in Appondir I and Tabre $\pi / A$.

(3.3) The Partioipatine and Executine Aeency may, after consultation with the Government, provide part or all of the expert services specified in paracraph (3. 1a) abovo, by sub-contract. 
Work Pian (cont inzed)

\section{E. PARTICIPATIOA AND COATAIBUTION OF THE GOVERMENT}

1. Counterpart contribution

(3.4) The Government ghall provide the following as a counterpart contribution in lind.

2. Peraonal services

Professional staff. . A total of $142 \ldots$ man-months of professional s.taff service. Within the total of 142.... man-months of professional stafe service minor adjustments of Individual post assignments may be made by the Govermment, in consultation with the Partioipating and Fxeouting agenoy, if this is found to be in the best interest of the projeot. Non-professional staff. In estimated total of .1326... man-monthe of nonprofessional etafe servioe.

b. Pellowshps

Local ealary for professional atafi awarded Special Fund followship while in fellowship otatus.

Student allowancea at en eatimated cost of $8 \ldots \ldots$...598...........

c. Lend and Balldings

Isund and buildings at an eatimated oost of $8 \ldots . .9 \%, 009$

\section{d. Equipwent and Sapplies}

Equipment and oupplie including installation, maintenance, repair, and operating costs of transport and all other equipment supplied to the project by oither the - Government or the Special Fund, at an estimated cost of \$ ...99.999......... c. Sub-contracts

Sub-contracts at an estimeted oost of $1.169,000$ 
Work Plan (cont inued)

\section{f. Mrcellaneous}

Miscellaneous services and facilities, including office furniture, equipment, atationery and supplies at an estimated cost of $\$ \ldots \ldots, 5,000$

c. Cost of transporting and handline of equipment

The cost of import and customs olearance.of project equipment; its trensportation, handling, storage and related expenses within the country; its afe custody, inmurance, and replacement if necessary, after delivery to the project site.

h. Records and Information

The Government gball make arailable to the project all existing published and unpublished records and information necessary for 1ts implementation. This will Inolude reports, maps, records and other data which, in the opinion of the Participating and Bxecuting Agency, would facilitate the operation of the project. 1. Housing

The Government undertakes to assiat project personnel in finding suitable housing accommodation at reasonable rents, whenever auch aseistance is required.

(3.5) The services and facilities summarized in paragraph (3.4) above are detailed in Appendix. . F.. and Table. . T/A

(3.6) The estimated cost of the counterpart contribution as detailëd in Appendix .If... below is based on the most realiatic information arailable at the time of drafting this Plan of Operation. It is understood that price fluctuations during the period of execution of the project may necessitate an adjustment of said contribution in monetary terms; the latter shall at all times be determined by the value of the services and facilities required for the proper execution of the project. 
Work Plan (cont inued)

\section{ii. Local Operatinc Costs}

(3.7) With reference to the paymente to be made by the Governient under Article $V$, paragraph $I(a)$ to (d) of the Agreement referred to in the preamble to this Plan of Operation, excepting the cost within the country for transportation of projeot supplies and equipment, which is a counterpart contribution, the Governwent/ghall

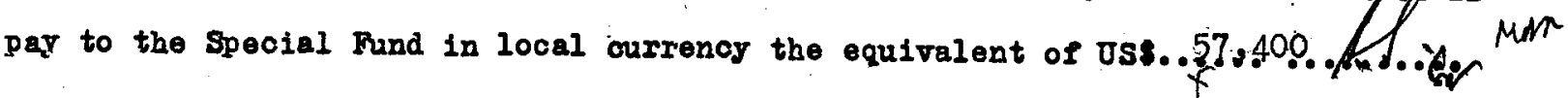
as a contribution towards locel operating costs. This amount represents 15 per cent of the totel eetimated coet to the Special Fund of foreign project personnel, including cost of foreign personnel of sub-contractors.

(3.8) The contribution towards looal operatins costs, the equivalent of os $\$ .57,400.6 .7$. ehall be deposited by the Gorernment in local currency to the credit of the UNDP Contributions Aocount No.. $8539 . . . . . .$. with. Peshten gpjerety Ink

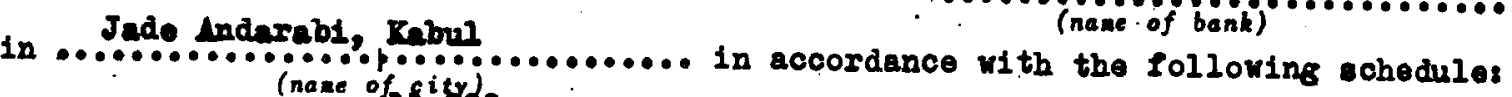

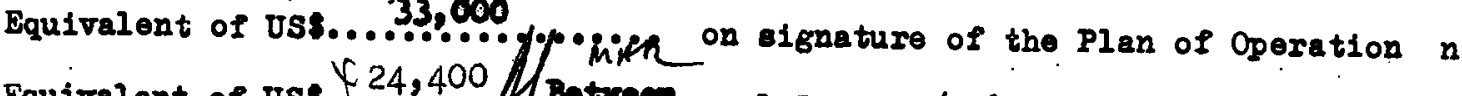

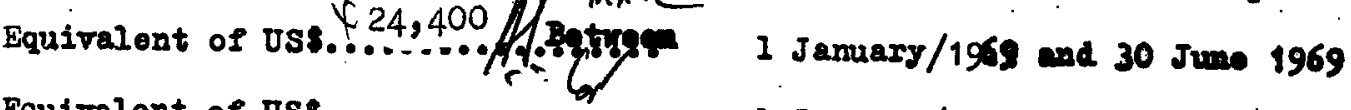
Equivalent of US\$................ on 1 Jamary/19.. Equivalent of US\$............... on 1 January/19.. Equivalent of US\$............... on $1 \mathrm{~J}$ anuary/19.. Equiralent of US\$................. on 1 Januery/19.. Equivalent of US\$................ on 1 January/19.. Equivalent of US\$................ on 1 January $/ 19 .$. Equivalent of US\$............... on 1 Jamuary /19.. The amount payable in each instalment is determined on the basis of the United Nations operating rate of exobange in effect at the date the payment falle due or at the date payment is made, whicherer is later. Payment of the above anounts on or before the dates specified le a prerequicite to operation. 
Work Plan (cont inued)

\section{Privileges and Immunities}

(3.9) The Partioipating and Executing Agency's contractors and their personnel (except Government nationals employed locally) shall have the right to the foilowing:

a. Immunity from legal process in respect of all acts performed by them in their offioial capacity in the execution of the projeots

b. Immunity from national servioe obligationas

c. Immunity from immigration restrictions;

d. The privilege of bringing into the country reasonable amounts of foreign currency for the purposes of the project or for pereonal use of ouch personnel, and of withdrawing any arch amounts brought into the country, or, in eccordanoe with the relevant foreign exchange regulations, ouch anounte as may be earned therein by exch personnel in the exeoution of the project; and

- The same repatriation facilities in the event of international crises as diplomatic envoye.

(3.10) All personnel of the Participating and Executine Agenoy's oontractors shall enjoy inviolability for all papere and documents relatine to the project.

(3.11) The Govexnment shall either exempt from, or bear the cost of, any texes, duties, fees or levies which it may impose on any foreign firm or organization which may be retained by the Participating and Bxeouting Agency and on the foreign personnel of any such firm or organization in respecti of:

a. The salaries or wages earned by such personnel in the execution of the project; b. Ing equipment, materials and supplies brought into the country for the purpose of the project or which, after having been brought into the country, may be oubsequently withdrawn therefrom; and

c. As in the case of concessions currently granted to the United Natione' experte, any property brought, inoluding one privately-owned automobile per employee, 
Work Plan (continued)

by the firm or organization or its personnel for their personal use or consumption or which, after having been brought into the country, may subsequently be withdrawn therefrom upon departure of such personnel.

(3.12) Tha privileges and immunities to which such firm or organization and its personnel may be entitled, referred to in paragraphs 3.9. 3.10 and 3.11. of this Plan of Operation, may be waived by the Participating and Bxecuting Agency where, in its opinion or in the opinion of the special Fund, the immunity would impede the course of justice and can be waived without prejudice to the successful completion of the project or to the interest of the Special Fund or the Participating and Executing Agency.

(3.13) The Participating and Executing Agency shall provide the Government with the list of personnel to whom the privileges and immunities enumerated above shall apply.

(3.14) In the event that the United Nations, the International Atomic Energy Agency or ans Specialized. Agency of the United Nations, participates in the implementation of this Plan of Operation, it is understood that thess organizations and their personnel shall be respectively accorded the privileges and immunities provided for in the Convention on the Privileces and Immunities of the Intermational Atonic Energy Agency or the Convention on the Privileges and Immunities of the Specialized Agencies. In pursuance of the latter Conventions or Agreement, as the case may be, each organization shall have the right to waive its privileges and immunities.

(3.15). Privileges and immunities of Participating and Fxecuting Afency and Special Fund personnel are covered by the Agreement referred to in the preamble to this Plan of Operation. 
Work Plan (cont inued) :

\section{c. ORGANIZATION}

B.16) Overall responsibility for the organization and execution of the project, including any portion which may be sub-contracted, reats with the Participating and Executine Agency which will plan and direct operations through the Project Manager, who, together with the other international experts, will be aseifned to the project by the Participating and Brecuting Agency itth the conourrence of the Government.

(3.17) Any sub-contractors employed on the project by the Participating and Executing AEency will be selected in accordance with the relevant regulations of the Participating and Ereouting Agenoy.

B.18) In the discharge of his duties the Project Naneger, after coneultation with the Co-Manager, shall:

(a) Be responsible for the detalled planning, administration and execution of the project includine timine and budgeting of the various elements and the preparation of technical reports;

(b) Assist in the selection of project counterpart personnel and auxiliary otaff, and assist in the election of candidates for Special Fund fellorships who will normally be chosen fron the counterpart project personnel;

(o) Supervise the experts and, in respect to technical matters, the counterpart personnel assigned to the project;

(d) Deternine training standards and supervise the local training of counterpart staff;

(e) Be responsible to the Participating and Executing Afoncy for all material, oquipment and transport, and the local disbursement of any funds furmishod to the project through the Partioipating and Executing Agenoy;

(f) Control the use of land; buildings, equipment and matorials, oupplies and other pruperty belonging to the Special Fund and/or the Particifating ani Executing Acency, or aseisnod to the project by the Covernment; and 
Work Plan (cont inued).

(g) Co-ordinate, as judgement indicates desirabie, the efforts of project personnel with that of other agencies and projects whose activities have bearing on this project.

(3.19) The Government Agency responsible for Government participation in the project shall provide the necessary technical and adminietrative support to the projeot and ensure the co-operation of other agencies participating in the project.

(3.20) The Government ahall appoint a Project Co-Hanager, with the/ oonourremee ar Fixecuting Agency, who will be assigned full-time to the project. Fe will oo-operate closely with the Project Manager in the acministration and execution of the project.

(3.21) In the discharge of his duties, the Co-Manager, after coneultation with the Projeot Manager, shall:

(a) Be responsible for all pbeses of the Governmentia partioipation in the project, including ensuring that Government contributions are made as scheduled, and that buildings, equipment, materials and facilities listed as counterpart contributions in kind in the Plan of Operation are arailable as needed and in due time;

(b) Submit for appointment or approval by the Government candidates for counterpart and auxiliary otaff poote and for fellownhipa previously agreed with the Project Manager;

(c) Be responeible for the adminietrative supervision of counterpart profeselonal and auxiliary personnel aselgned to the project,

(d) Assist the Project Manager in oo-ordinating project aotivities with the activitics of other Covernmental Agencies and projects in fields of work related to the project. 
(3.22) The Govermment shall appoint an Administrative Officer, with the concurrence of the Fxecuting Agenoy, who will work under the supervision of the Combanager and in olose cooperation with the Project Hanager and with the internationally recruited Administrative Officer (if there is one). The Government Administrative Officer shell be responsible for servicing the project on administrative matters such as acounting, storekeeping, purchase of materials and supplies, meintenance of equipment, peyrolls and servicing of the experte. He ohall be responsible for the oare and maintenance of equipment and supplies and the supervision of administrative personnel. He shall also be responsible, in consultation and co-operation with the Resident Representative of the United. Nations Development Programme, for the appropriate registration, lioensing, and insurenoe for the duration of the projeot of all motor rehioles supplied through the Partioipating and Exeouting Lgenoy.

(3.23) The intermationally recruited Administrative officer shall be responsible to the Frecuting Agenoy for all material, equipment and transport, and the $200 a l$ disbursement of ang funde furnibhed to the project through the frecuting 4 genoy. 
Work Plan (cont inued)

(3.24) All material and equipment provided for in the Plan of Operation will be used exclusirely for execution of the project.

(3.25) All equipment and eupplies whioh are purohased from Special Dund resouroos remain the property of the Speoial Bund in whose name it is held by the Participating and Executing Agency. This provision shall also apply to equipment, the title to which is temporarily transferred to the country to comply with the legielation of the country or for the convenience of project. operatione.

(3.26) Equipment which is purohesed from Special Nund resources whall be clearly marked with the insignis of the Speoial Fund and of the Fartioipating and Breouting Agenoy.

(I/A) is the project.develope, the Projeot Nanager and the international experts will delegate an increasing amount of their reaponsibilitieg to the Co-Nanager and the respective counterpart steff so that, at the ond of the perlod of Speolal Fund aupport, the national projeot personnel will be competent to enare the officient contimation, or follow-up, of project actirities. 
Vork Plan (cont inued)

D. SEquENCE OF OPERATIONS

(3.27) The Participating and Executing Agency shall commence execution of the project upon receipt of written authorization to do so from the Adminiatrator.

(3.28) Not including the period of active pro-operational planning at the project eite by Partioipatine and Executing Agency and Government project personnel, field operatione

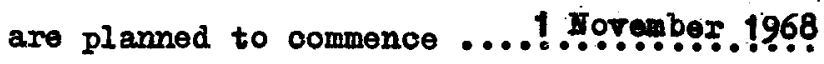
continue for approximately ........................... years thereafter.

(3.29) The planned Sequence of Operations for the project is set out in wome detall in Appendix IV, Sohedule of Operations. 


\section{BUDGET}

(4.1) The estimated cost of the cervioes and facilitios to bo provided for the project is detalled in the Plane of Expenditure appended to thie Plan of Operation. Funde will be provided by the Special fund and the Government as indicated belows

(a) i. Mllocation by the Special Fund ......... Consinting of:

Special fund contribution .......... Uss Gorernment contribution toward local operating costs ............uss

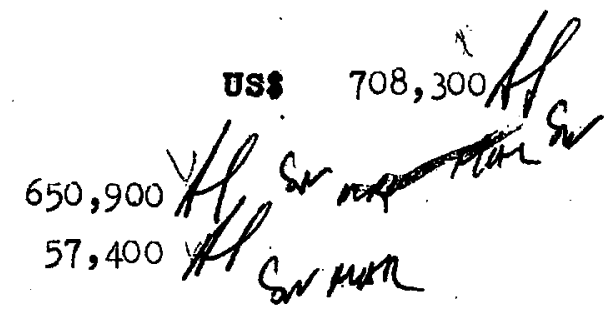

2. Counterpert contribution in kind of the Govornment

Us:

290,440

3. Countexpart contribution in cash by the Government .

(b) 1. Allooation the Special fhund Consisting of:

Special Fund oontribution ..........uss

Covernment contribution towarde local uperating cost. ............uss $\mathrm{J} / \mathrm{A}$ Goveranent counterpart contribution in caeh .............tss

2. Counterpart contribution in kind by the Oovernment 


\section{y. Mraponts}

(5.1) The Participating and Exeoutine Agenoy shall submit periodio progress reports to the Speatal Find on the implementation of the profect. Suoh reports shall, as appropriate, includs an up-to-iats Schodulo of Operations. The timing and frequenoy of these reports are determined in operatine procedures agroed betweon tha special Fund and the Participating and Exscuting Agenoy.

(5.2) The Participating and Brecuting Afenoy and the Goverament shall exohange reports, the content and timing of which shall be agreed by oxrespondence.

(r/L) Ihe Partiolpating and Erecuting Soncy will aubmit to the Government and to the Special Hund, at the end of each year, a finencial statement, relating to the oash counterpaxt contribution described in paragraph ............

(5.3) The Participating and Exeoution Agency and the dovermment shail, at the end of each oalendar year, submit to the Special Fund a joint certified inventory of project oquipment purchased from the Speoiel Fund allooation and for which titlo Iamains with the Special Fund.

(5.4) As soon as possible folloxing the oonolusion of project operations, and not later than six months from that date, the Paxticipating and ixeouting Agency shall submit a final oomprehensive report on the project to the Adminiatrator for presentation to the Govermment

\section{v1. Changes in the plan of opération}

(6.1) On the basis of periodic revieks of projeot activities the three parties to the project shall, as appropilete, confer to determine if any modifioations to the plan of Operation be required. All agroed modifioations shall be reflected in Ad fustments or Amendments to the Plan of Operition. 


\section{vII. STEPS TO BE TAKEN AT THE COMPLETION OF SPECIAL FUND assistance to the project}

(7.1.) Within three months of receiving the final report, the Government shall submit to the Participeting and Executing Agency and the Special Fund a report on the benefite derived from the project and the actions planned by the Government to implement the recommendations contained in the final report.

7.2) At the successful conolusion of the project the Government, the Participatine and Executing Agency and the Speciel Fund ahall consult with a view to transfersing title to the Government, or to an Agency nominated by the Government, (of part or all) of the equipment provided by the Speoial Fund. Suoh consultations shall not prejudice the right of the Special sund to retain title to that part of the equipment whioh is not needed for the continued operation of the project or for activities following direotily therefrom, or which is more urgently needed by other United Nations Development Programme-assisted projeots.

Agreed, on behalf of the Parties, by the undereigned:

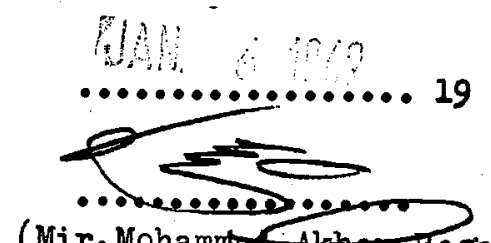

(Mir. Mohamntar Pexa)

Minister of Agroand Irrigation

Royal Gort. of afghanistan. Government- of Afghnnistan •.....................

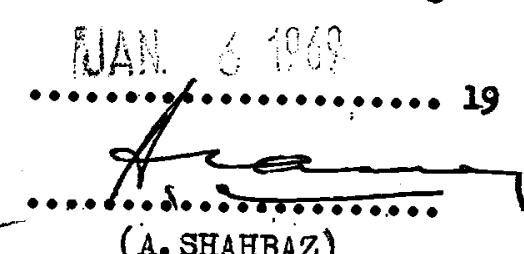

(A. SHAHBAZ)

Representative

United Nations Dev. Programme.

Onited Hations Devolopment Programme

(Spectal Dund)

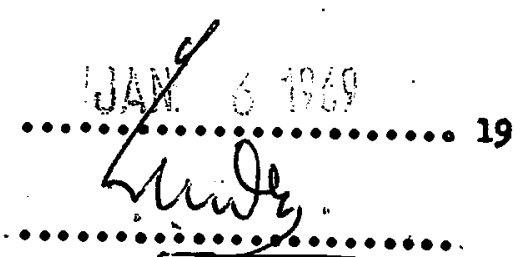

(S.K.DEY)

FAO Ropresentative,Kabul.

Food and dirioul tare Organization of the United Jationa 


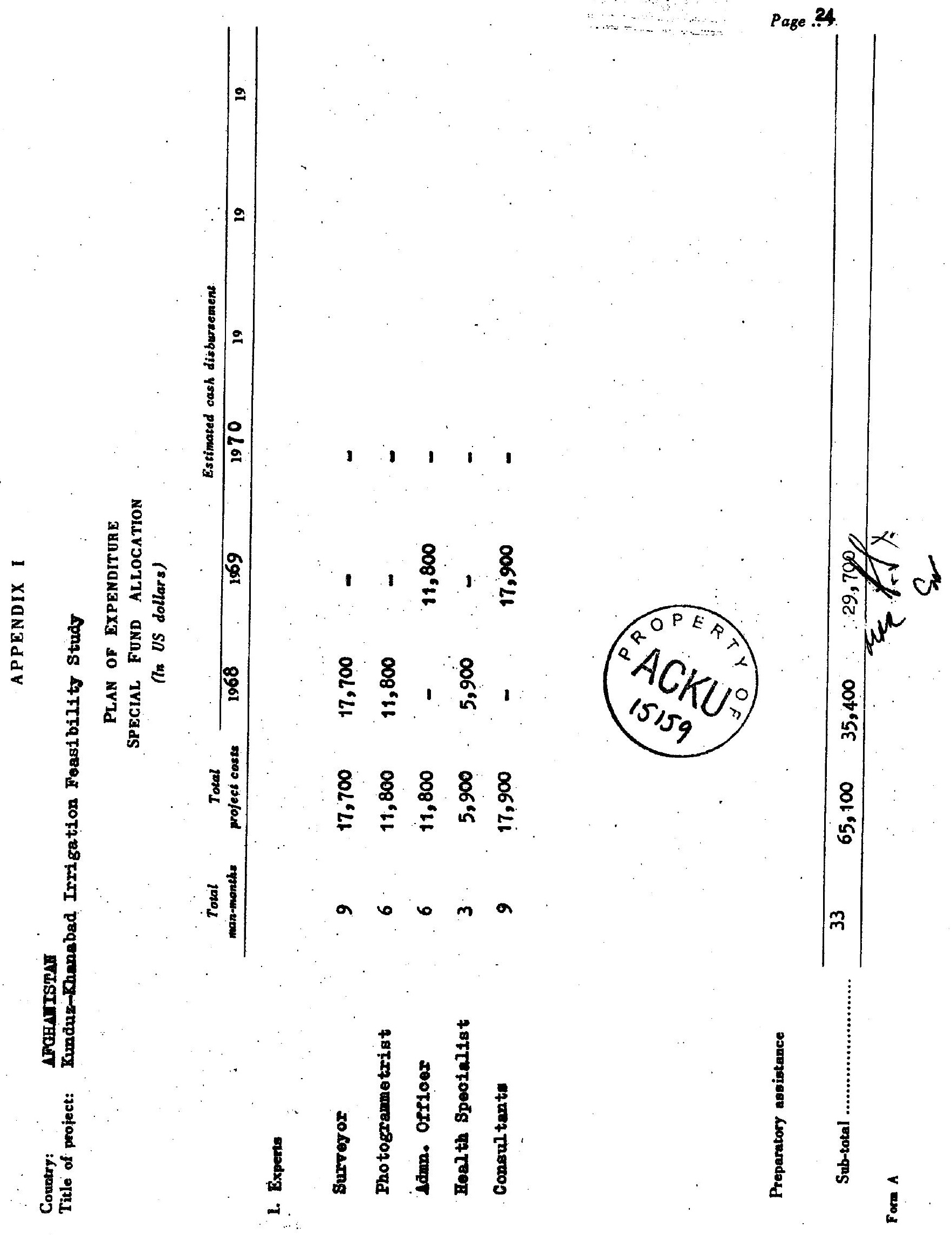




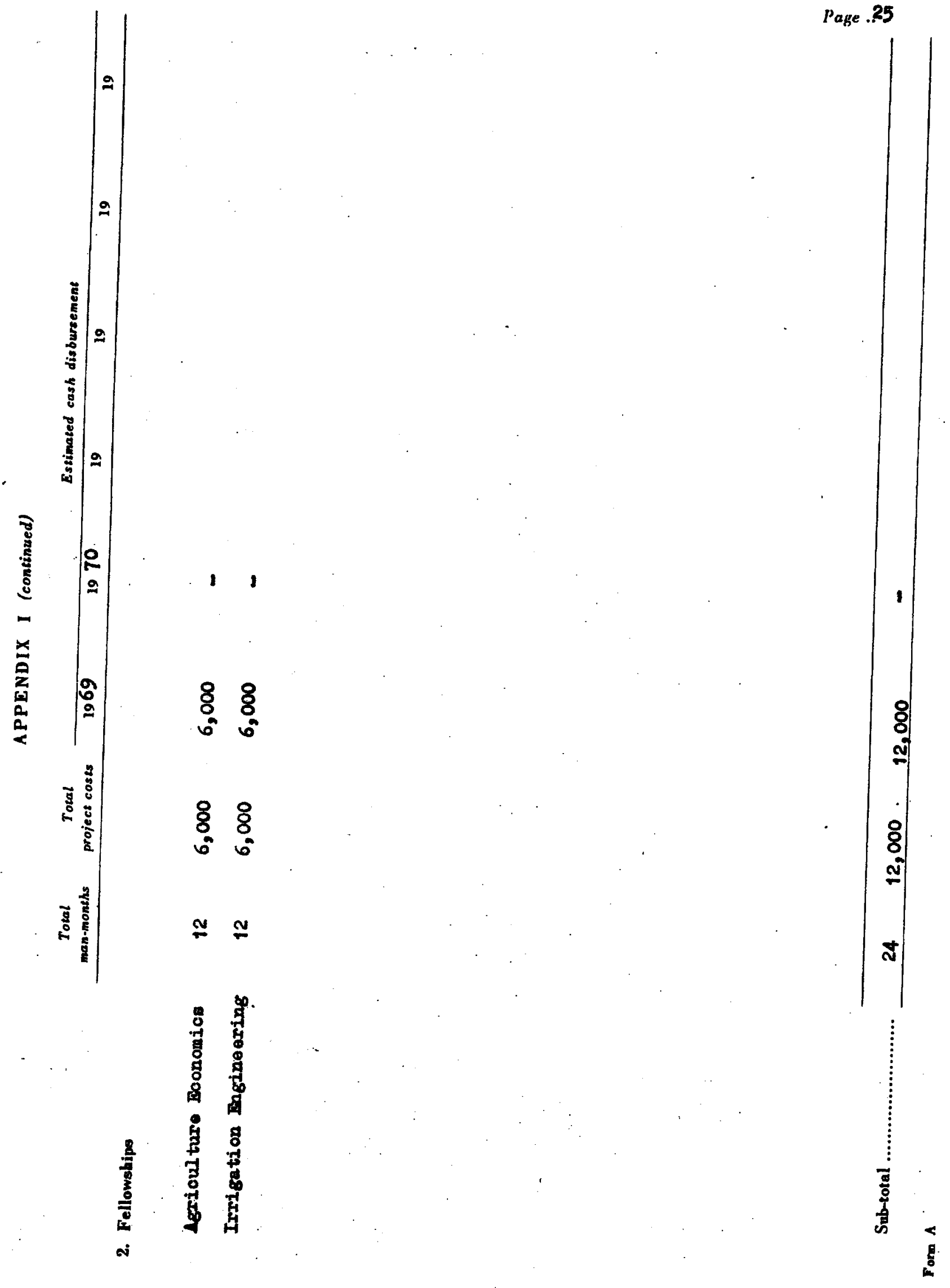




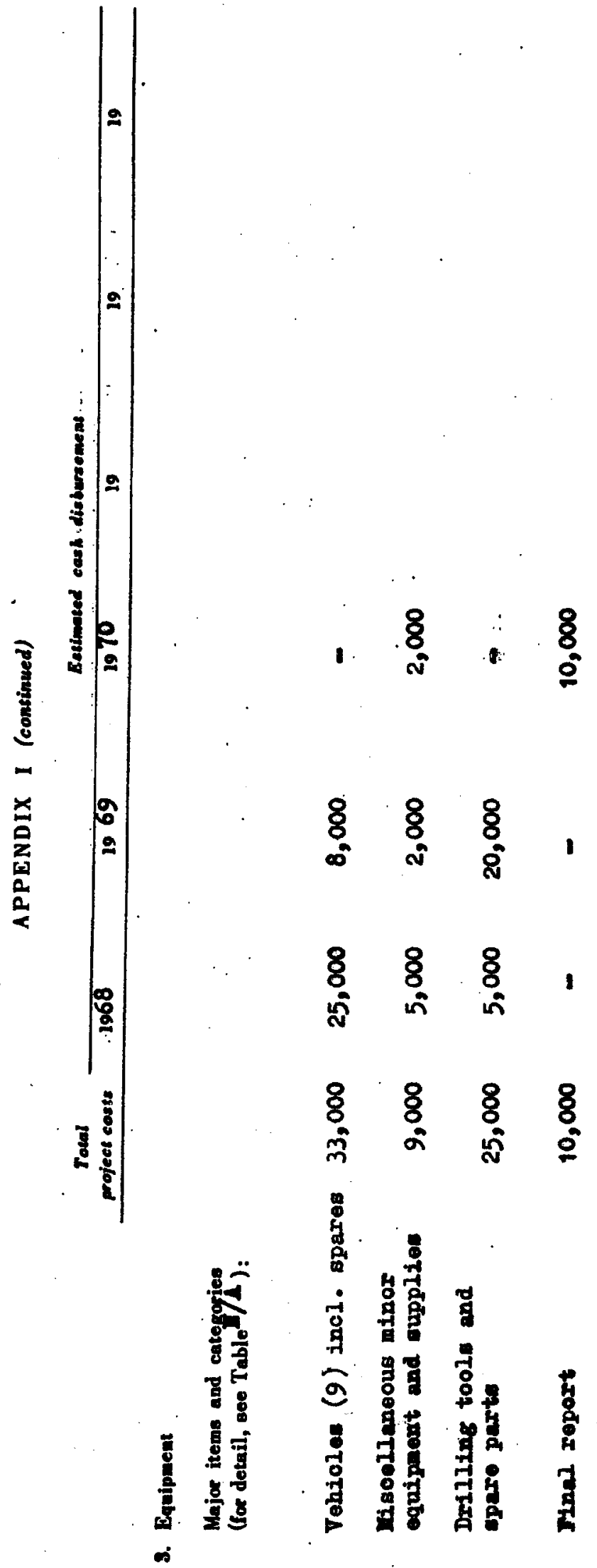




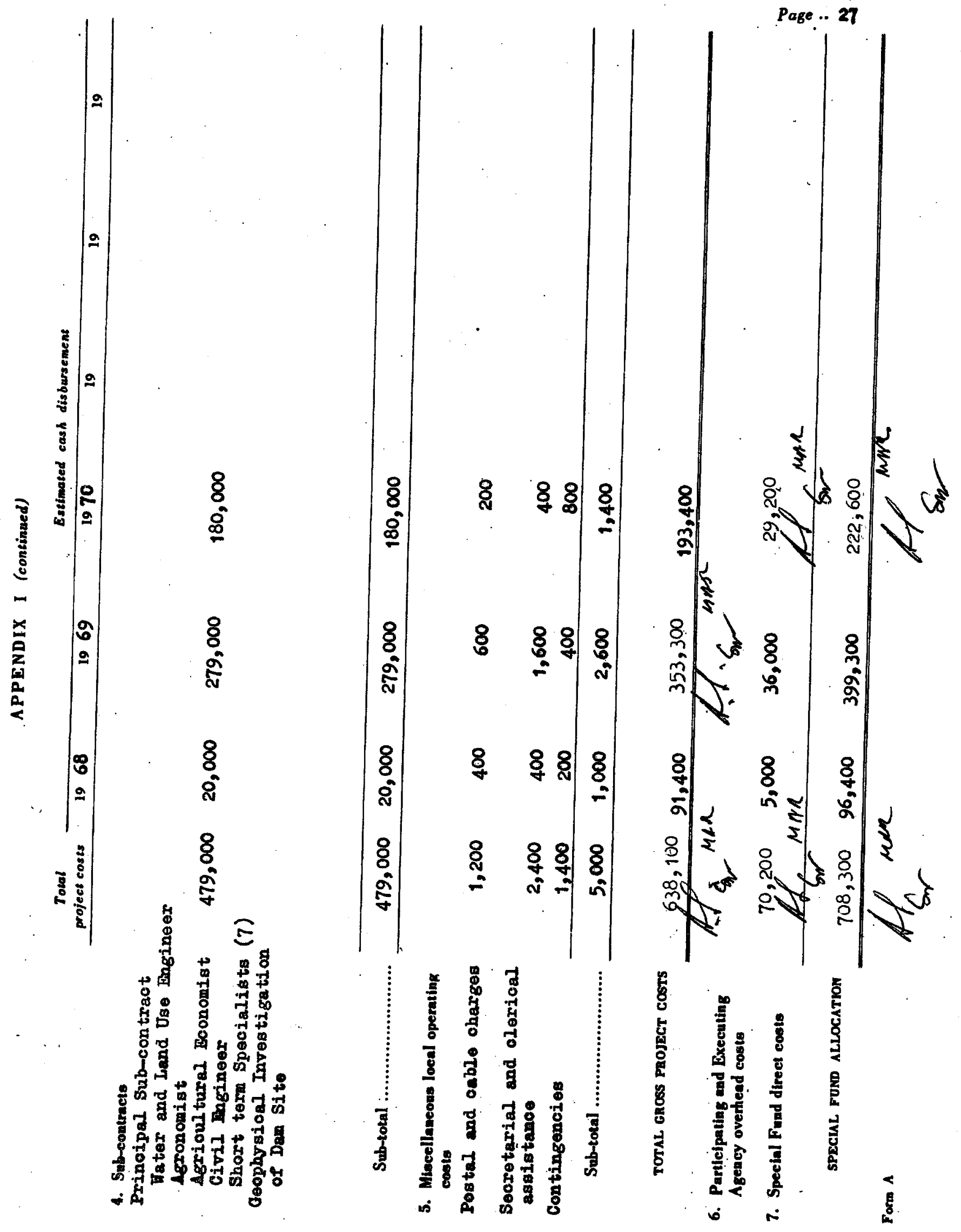




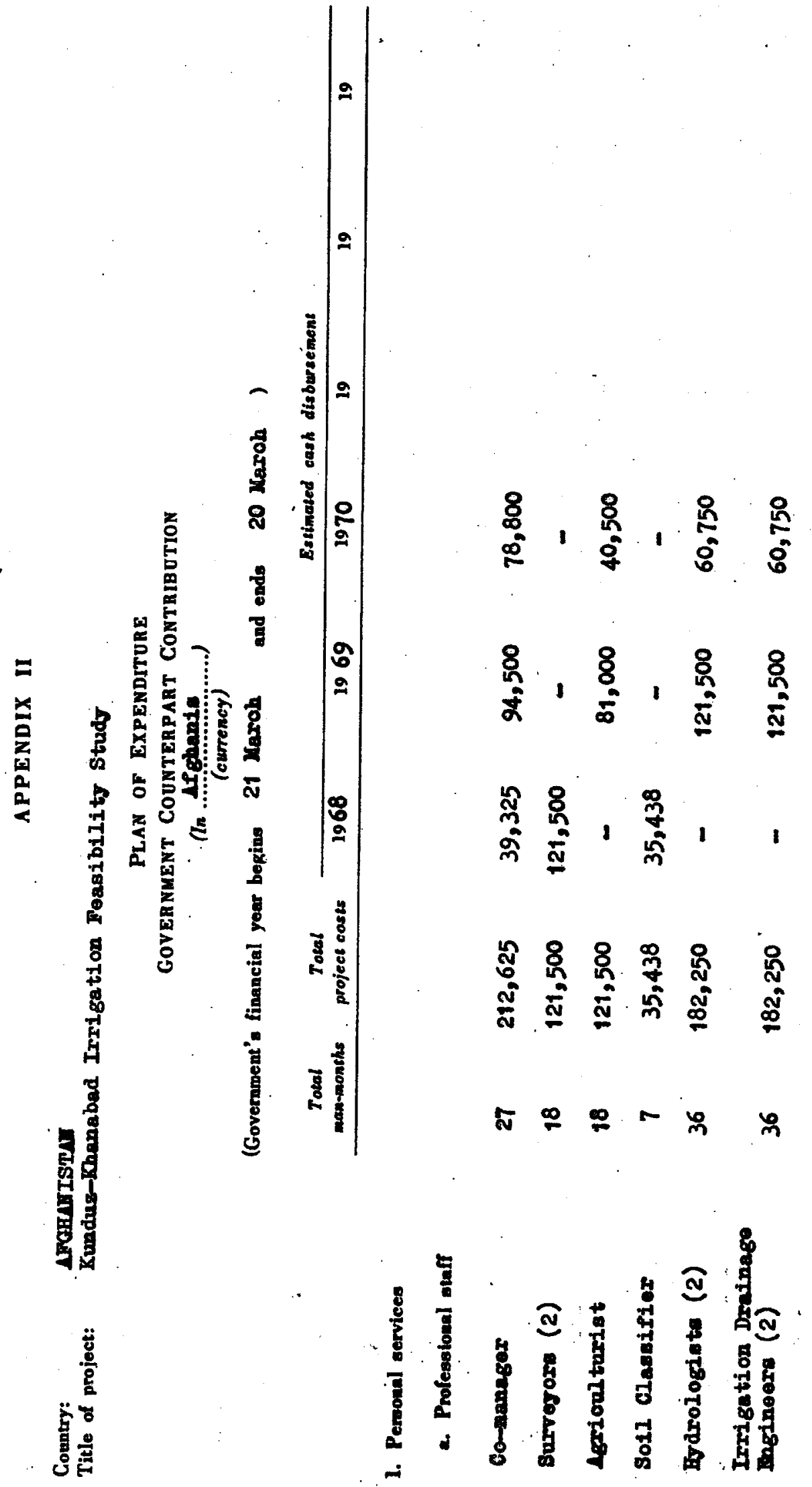




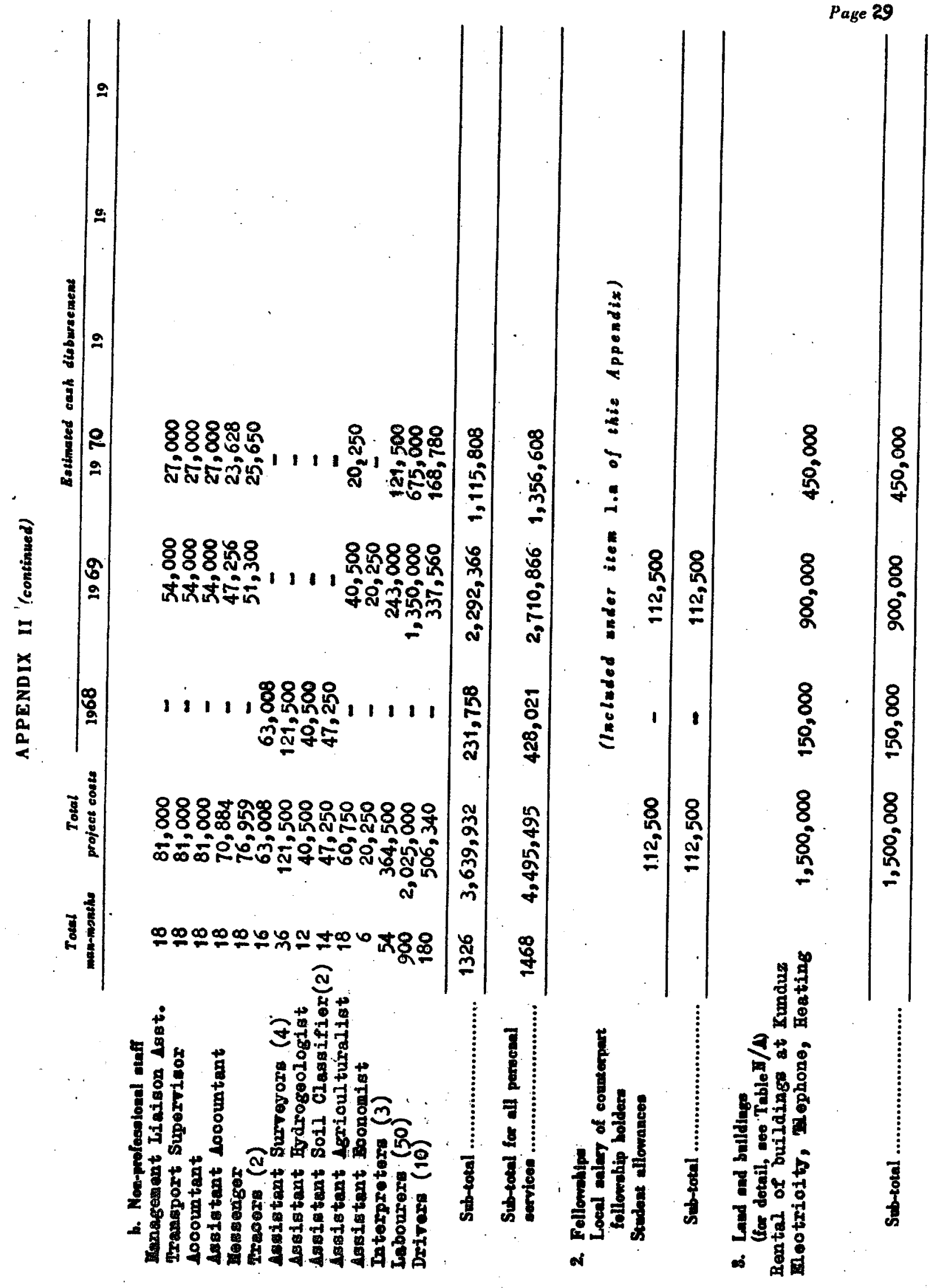




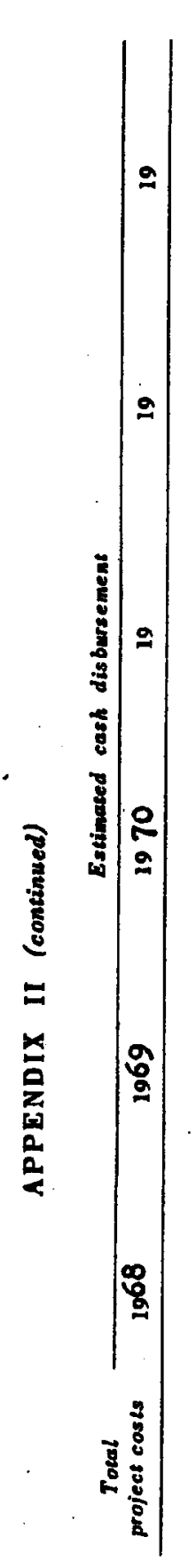

Page .. 30

8
8
8

8
$\$$
$\$$

\&

8
8
8
0

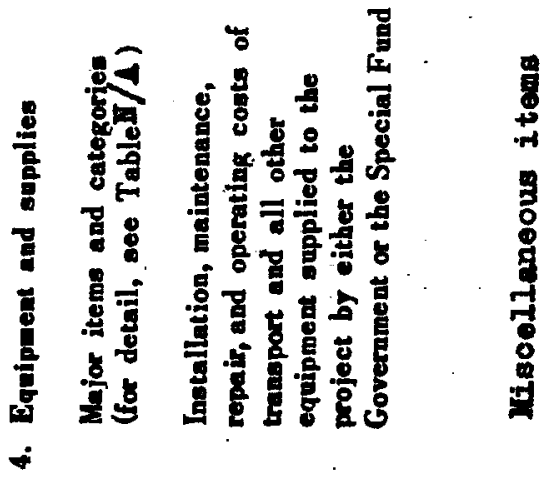




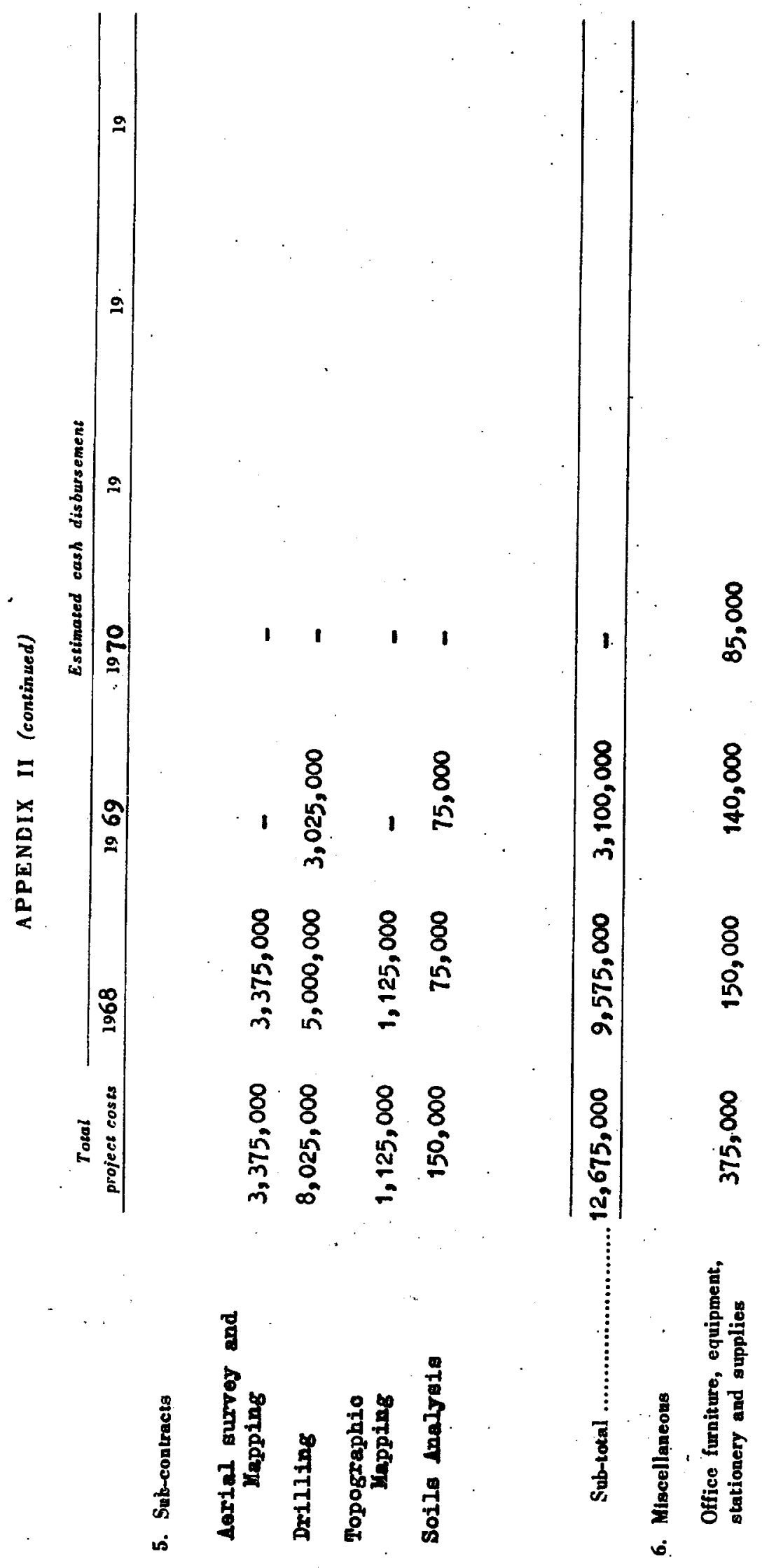

Page . 31

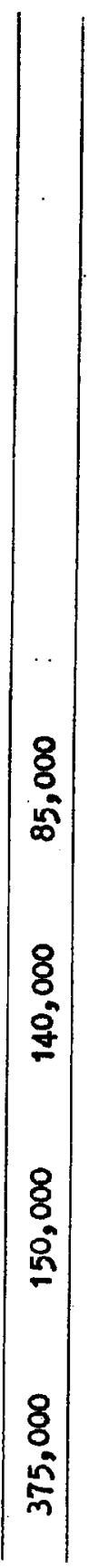


Page 32

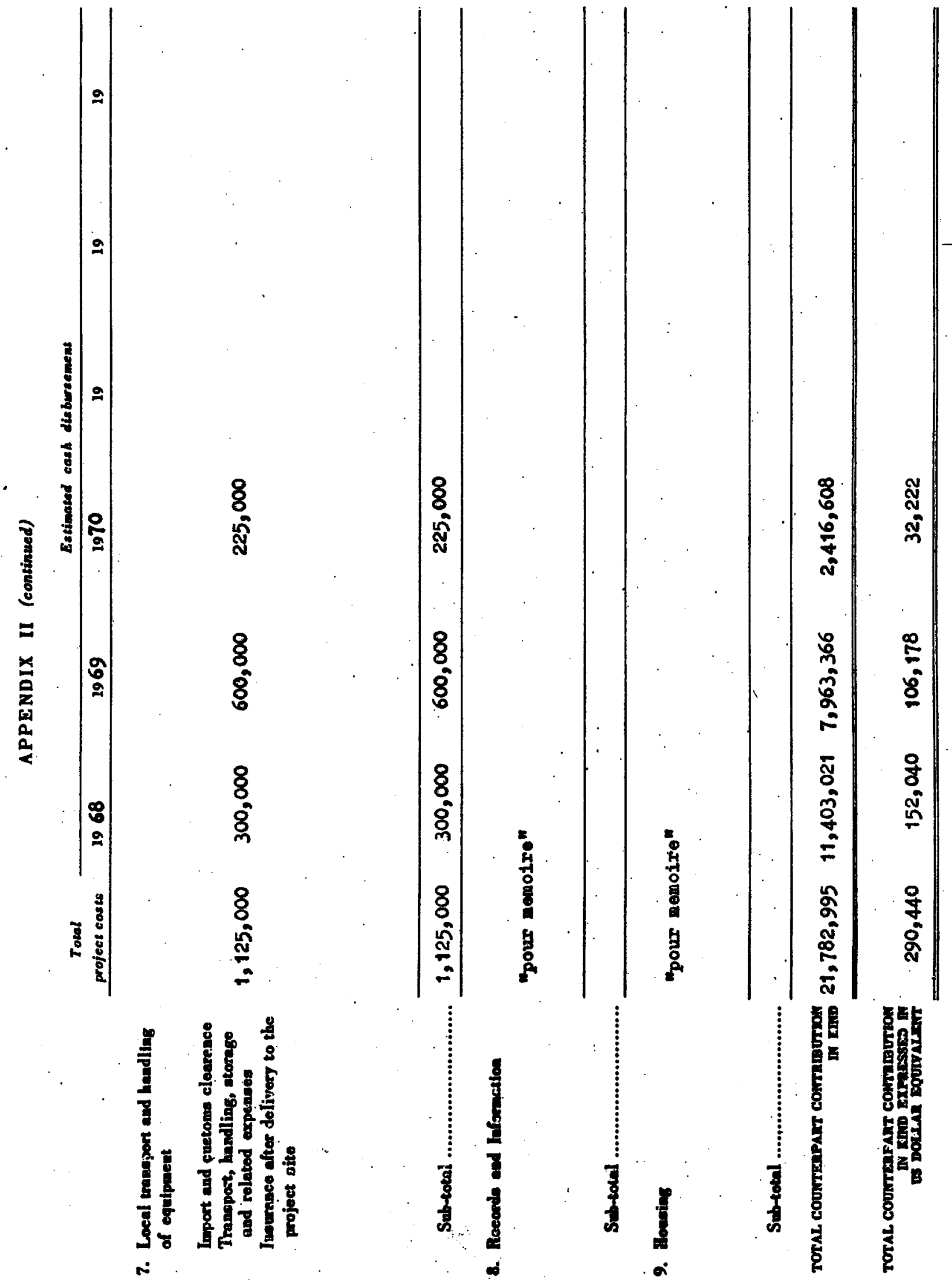



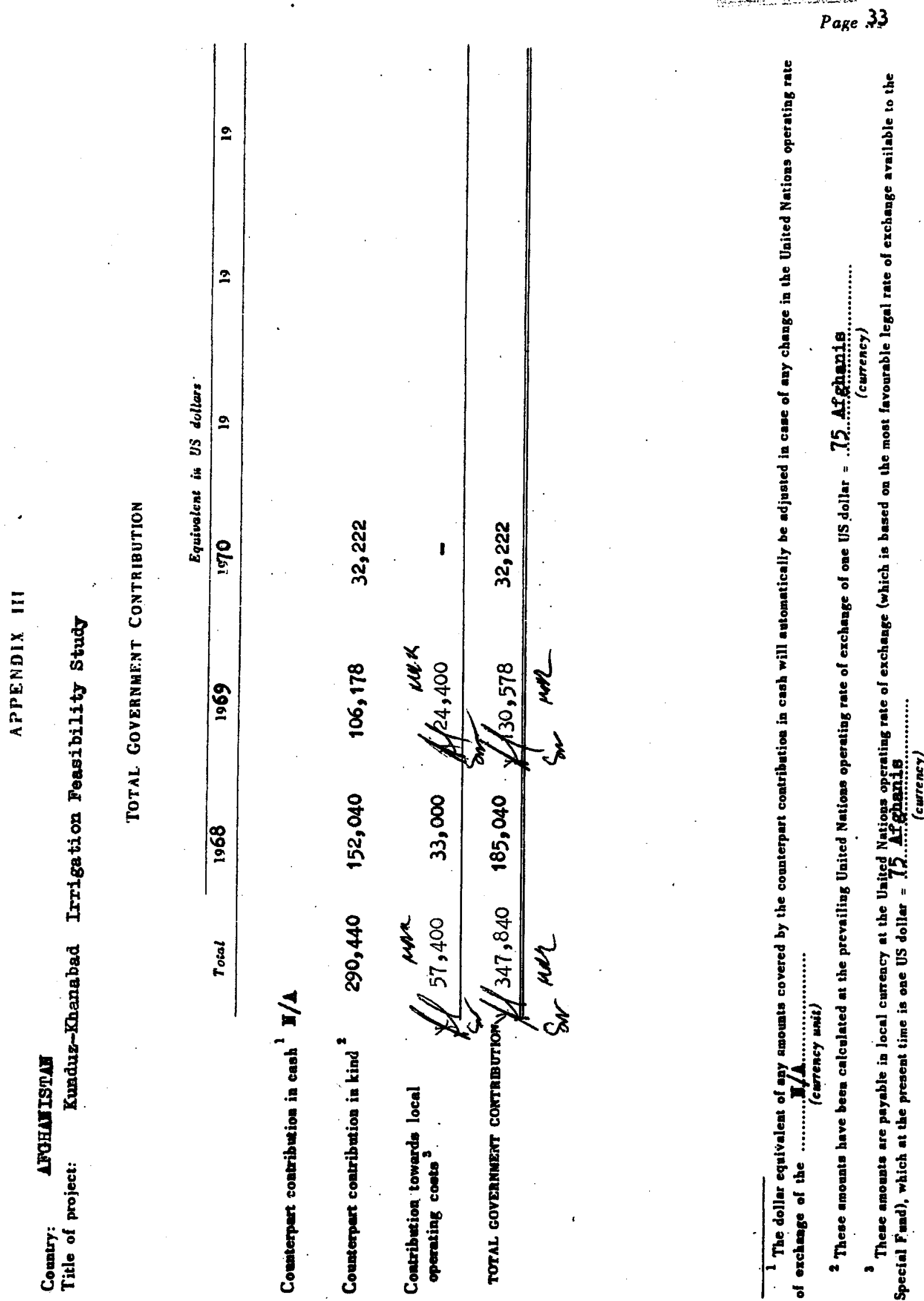


\section{LPPEIDIX IT}

\section{Country, AFGHAIISTS}

THtle of Project, Kunduz-Khanabad Irrigation Feasibility StudJ

\section{SCHEDULE OF OPERUTIOAS}

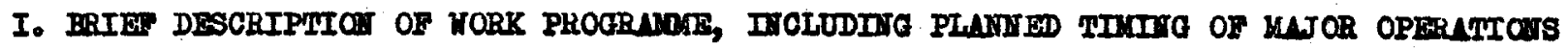

(IV. 1) Jpan recoipt of authorization to commenoe exocution of the project, the participating and Frocuting spenoy shall make arrangements for the exooution of the activities of the project as provided in the Plan of Operation, including the nogotiations for the selection, after oonsultation with the Government, of the sub-contractors and appointant of the Projeot Manager and of the other international experts required for the project. Upon the arrival of the Projeot Maneger at his duty station the Govermment will appoint a Froject Comlanager, aooeptable to the Partioipating and Fracuting sgenoy.

(TV.2) The Projeot Xanager, together with the Projeot Co-lanager, and after oonsultation vith the Corernment, shall propare ganeral Plan of Nork, the main aspoot of with are 2isted in this Sohodule of Operations, for oarrying out the projeot oporations. This Plan of Nork shall be oubmitted, within threo monthe after tho Projoct Ianager's arrival, to the Partioipating and Breouting lgenos for approvel. It shall inolade suoh itens as an orerall sohodule for the operations, detailed lis ts of equipment, supplies and materials to be purchased, staffing plans, and arrangements for traneport, and other cervioes. Proviaions shall be and in order to take account of suggestions of the reapeotive experts when they arrive in the oountry.

(IV.3) Tho Project Vanager, together with the Projeot Co-llanager, shall also propere a Jorward Plan of thork for the firet 6 monthe of the project operation, outlining all details of the activities to be cerried out during thie period. Mhereafter - Forward Plan of Vork for baoh 6 month period during the term of the project chall be propered and aubaltied for approval to the Partioipating and rrocuting 


\section{APPENDIX IV (continued)}

I. (continimed)

Lganoy and shell serve as a control on the projoot aotivition during. the period to which it epplies.

(IV.4) Kinor adjustmente in the schedules for manning the projeot and provision of other factlities may be made when agreod upon by the Projeot Manager and the Projeot Co-llanager after consultation with the Government and approved by the Headquarters . of the Partioipating and Ecocuting Agonoy, if this is found to be in the best interest of the projeot.

(IV.5) The Govermment will assign to the projeot the oounterpart personnel in accordance with the manning table of the Sohedule of Operations, and deliver the physioal facilities to be furnished by the Oovernment as outlined in this Sohedule.

(IV.6) Orders for equipment and supplies, whioh the Government will provide as oontribution in kind, shall be placed in due oourse to onsure avallability of these items at the appropriate time.

(IV.7) During the first year of the project operations the following activities will be undertaken.
a) The Government will oomplote the aerial surver work and reproduotion and printing of mape.
b) Geophraical aurroys will be carriod out.
a) Drilling operations vill oommenoe.
d) Holologion invostigations wll comence.
-) Soil Survey will bo oxoouted and land olassifioation oommenood.
f) Studies of crop rater requirements will ocmence.
c) Roviow of agrioultural prection will comanoe.
h) L reviou of land tenure aystems will be made
i) In-service tratning of sfehan personnel will oommenoe.
j) the award of fellowripto will be nado. 


\section{LPPEXDIX IV (continued)}

I. (continued)

(1.8) During the second year:

a) Drilling operations will oontinued.

b) 耳jdrological investigations rill continue.

c) Land classification will be continued.

d) In appraisal will be made of drainago and salinity problems.

-) Fingineering designs will be prepered.

f) Studies of orop rater requirements will continue.

8) Hovien of agrioultural practicos will continue.

h) 1 review of tonure aystems will be made.

1) Studies of farm budgets, agrioultural credit, markets, co-operatives research facilities, extension services, price policies, sociel factors, health aspects and organization and management problems will be made.

j) In conomio evaluation and financial analysis will bo made, and a feasibility report prepared. 

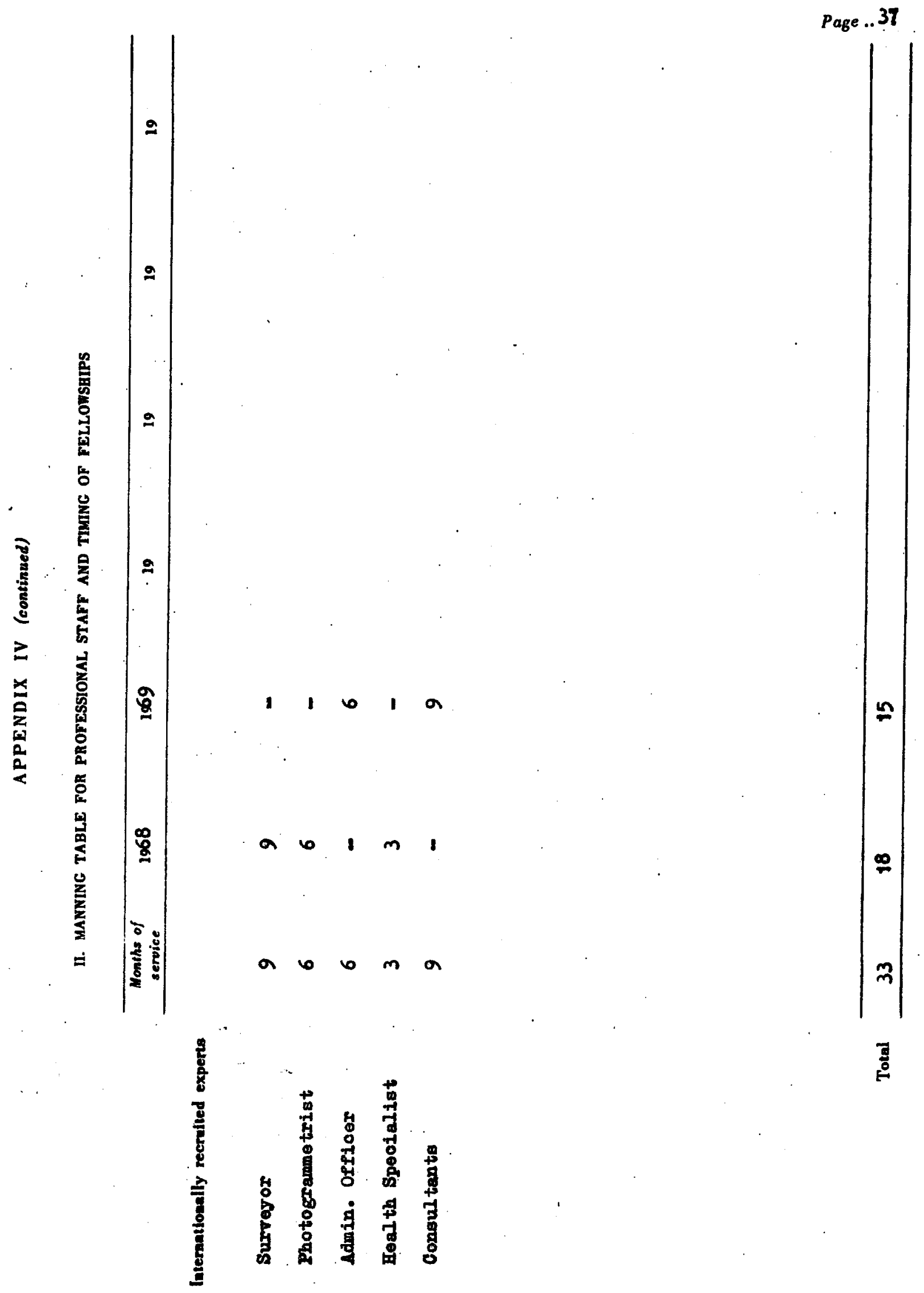


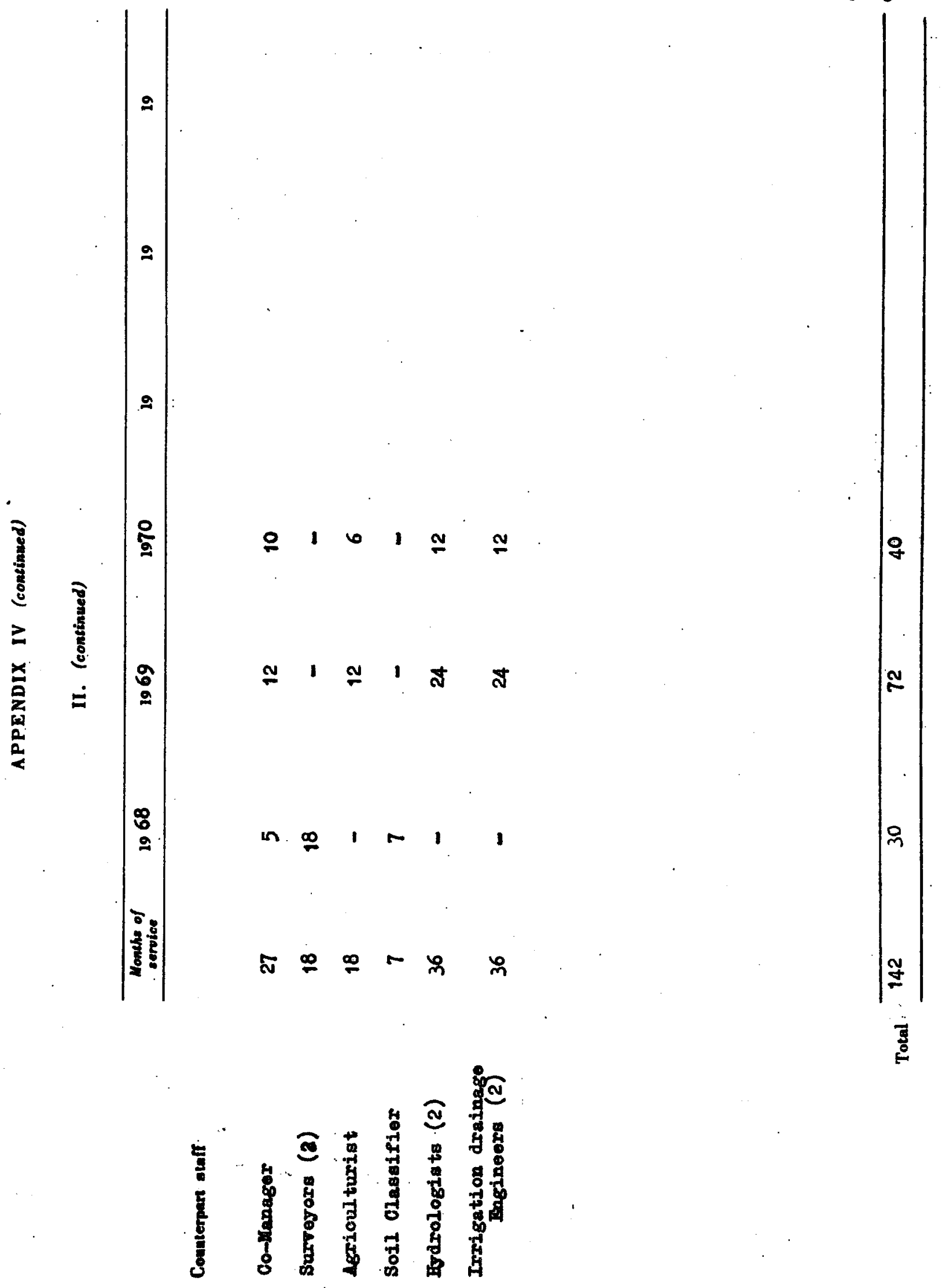




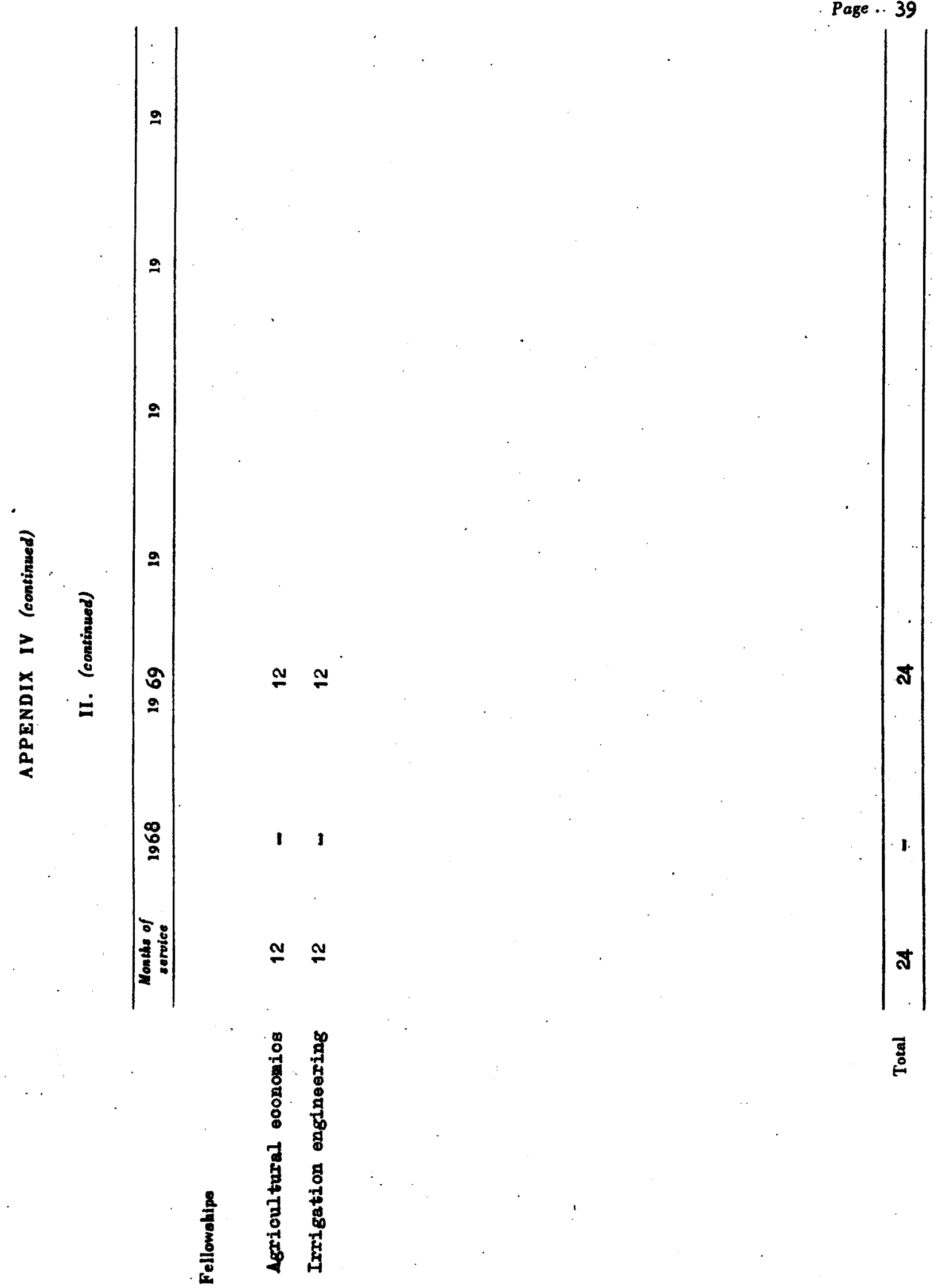




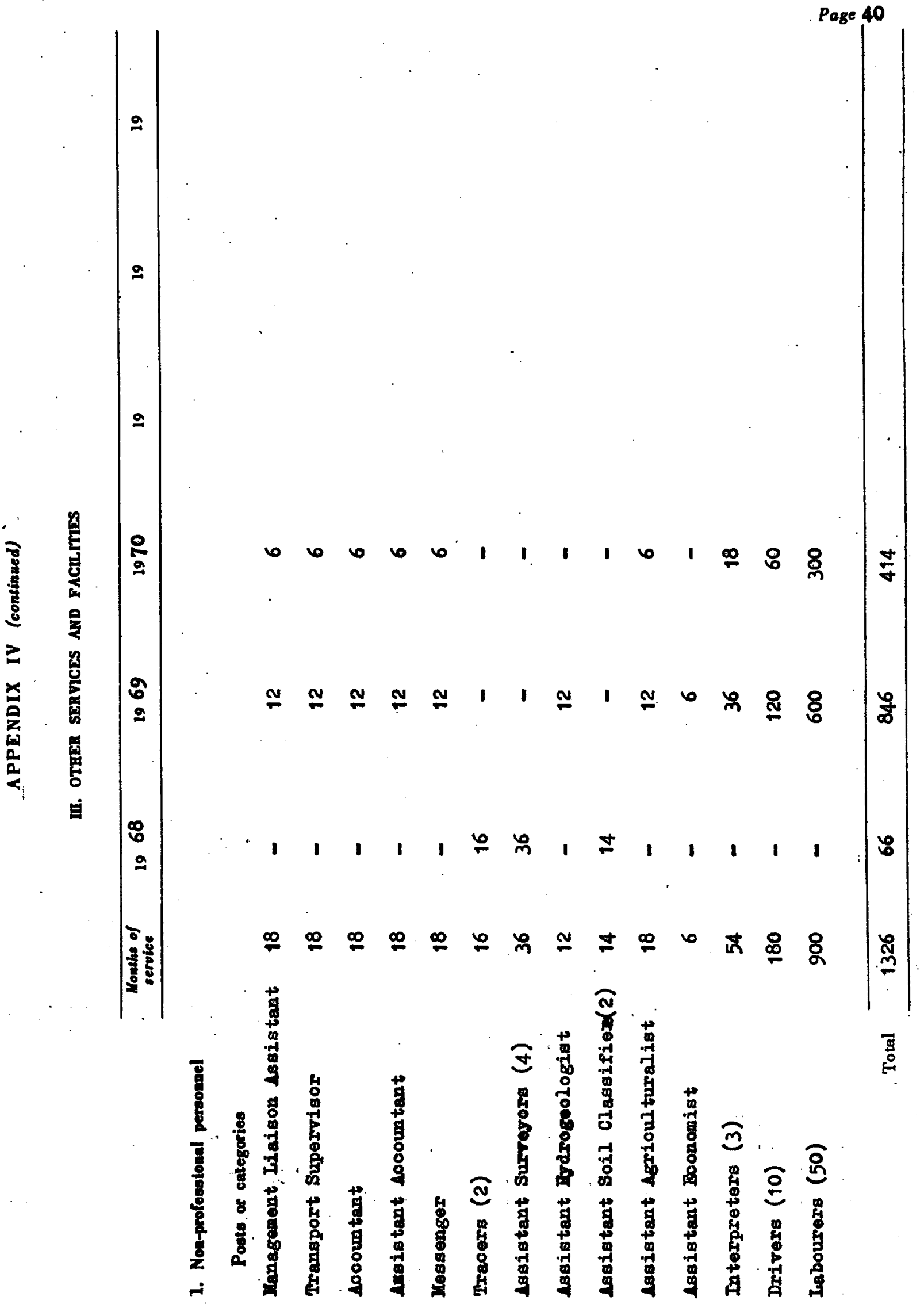




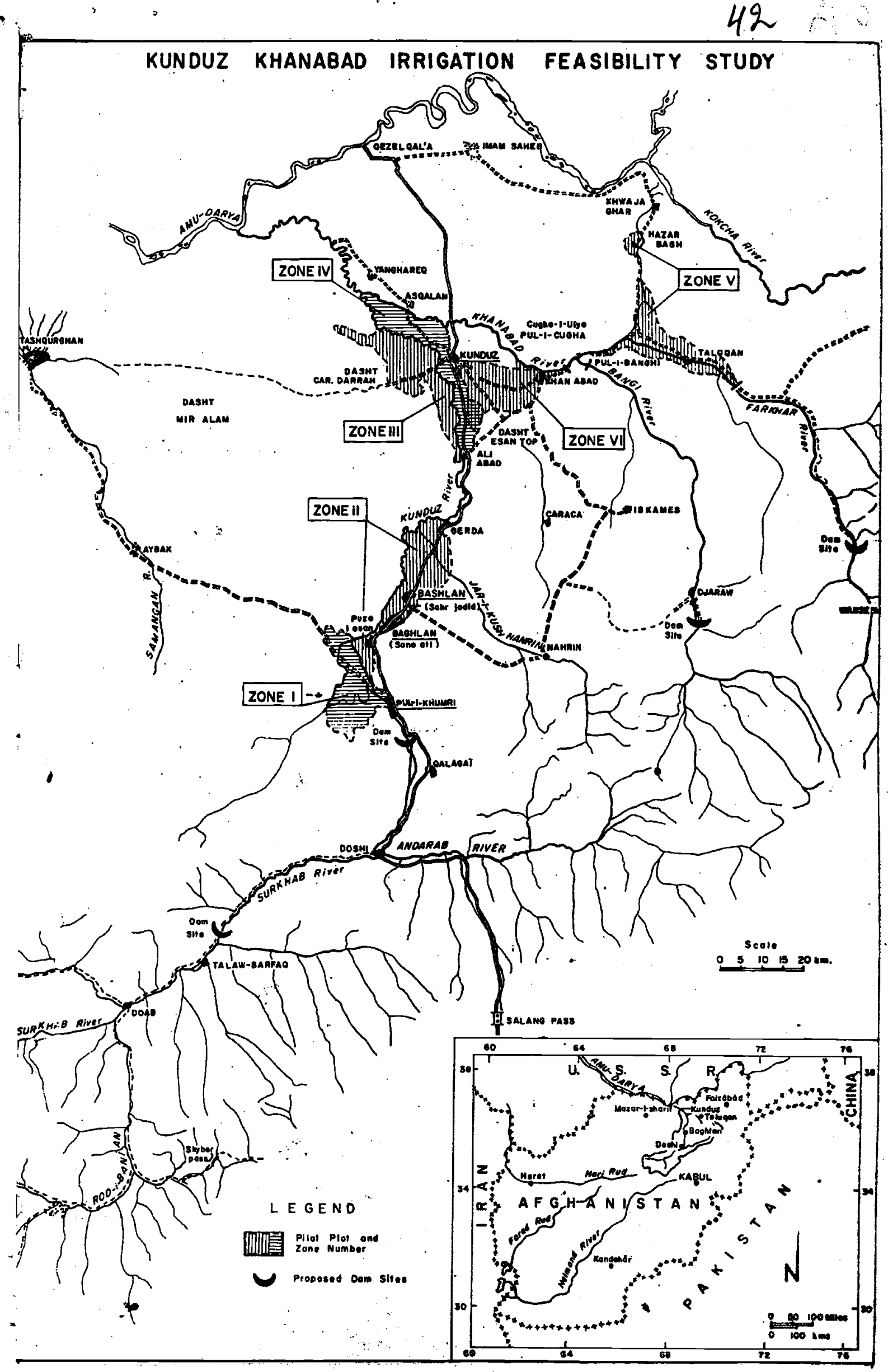




\section{APPENDIX IY (continued)}

III. (continted)

Th be nade nuaibble

2. Land and Enildings

Rentel value of offices

(9 roome) at Kunduz

November 1968 
III. (continued)

3. Equipeent

A. To be provided by the Special Fuad Major iteme and categories (for detail, see Table $\mathrm{H} / \mathrm{\Lambda}$ )

Vehioles (9)

Yovenber 1968

Kisoellaneous Kinor equipment and supplien

es required

Drilling toole and apare parts

Novombor 1968

to

Naroh 1969

B. To be provided by the Governent

Major item and categories (for detail, wee Table $\mathrm{I} / \Lambda$ ) 


\section{APPENDIX IV (continued)}

III. (continued)

4. Other services and facilities

$\frac{\text { To be made evallable }}{\text { Monsh }}$

Aeriel photography

April 1968

Haps as soele $1: 10,000$

September 1968

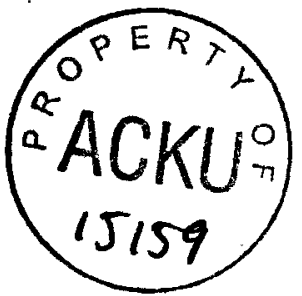

